\title{
A Molecular Perspective on Oscine Phylogeny, with Special Reference to Inter-familial Relationships
}

\begin{abstract}
Masanao HondA ${ }^{* * *}$ and Satoshi YAMAGISHI
Department of Zoology, Graduate School of Science, Kyoto University, Sakyo, Kyoto 606-8502, Japan

Portions of mitochondrially encoded $12 \mathrm{~S}$ and 16S rRNA genes were sequenced from 15 Oscine Passerine families in order to infer preliminary interfamilial relationships among the oscines. Our results, derived from combined sequences ( 881 base positions), suggest that the Oscines are comprised of at least three distinct lineages. Our results do not support the phylogenetic hypothesis based on DNA-DNA hybridization data. Furthermore, our data on inter-familial relationships, for example the wide separation of the Paridae and Sittidae, also contradict the previous relevant hypotheses based on morphology.
\end{abstract}

Key Words: Mitochondrial DNA, Oscines, Passeriformes, Phylogeny

The Passeriformes is the largest order of extant birds and includes over 5,000 species, representing approximately half of current avian species diversity (e.g. Bock \& Farrand 1980, Bock 1982). Although this order shows striking morphological diversity in bill and tail shape, considerable anatomical data support its monophyly (e.g. Bock 1982). This order is often split into two suborders, the Oscine and Suboscine, on the basis of syringeal structure (but see Bock 1982). The Oscine is also considered to be monophyletic on the basis of morphological data (e.g. Miskimen 1963, Ames 1971, Raikow 1987, Prum 1992, 1993).

There have been a number of debates regarding the inter-familial relationships and classification of the Oscines, and most of these arguments have depended on morphological characters (e.g. Mayr \& Greenway 1956, Amadon 1957, Cracraft 1981).
However, little consensus has yet been attained on their higher-level classification and phylogeny due to the scarcity of phylogenetically useful information in these characters. Phylogenetic analyses on the basis of biochemical data are, therefore, expected to contribute considerably to a solution to this problem (e.g. Barrowglough 1992).

Since the 1960 s, certain authors have, on the basis of data from egg-white protein, tried to elucidate avian phylogeny (e.g. Sibley 1970, Sibley \& Ahlquist 1972). Despite their enthusiastic efforts, however, little progress has yet been made towards a solution of relevant problems including those relating to the most basic issues (Barrowglough 1992). Later, the same researchers re-addressed avian systematics on the basis of DNA-DNA hybridization data (e.g. Sibley \& Ahlquist 1990), but their

* Corresponding author, E-mail: g019002@lab.u-ryukyu.ac.jp

** Present address: Tropical Biosphere Research Center, University of the Ryukyus, 1 Senbaru, Nishihara, Okinawa 903-0213, Japan 
work has received considerable criticism (e.g. Harshman 1994, Mooers \& Cotgreave 1994, but see Bleiweiss et al. 1994, 1995). Although DNA sequence data are known to provide useful clues to the solution of various problems pertaining to avian phylogeny (e.g. Mindell et al. 1997, Klicka et al. 2000, Tuinen et al. 2000), no molecular studies have been undertaken addressing the whole scope of passeriform phylogeny (e.g. Chikuni et al. 1996, Lovette \& Bermingham 2000).

In the present study, we partially sequenced mitochondrial $12 \mathrm{~S}$ and $16 \mathrm{~S}$ ribosomal RNA (rRNA) genes from representatives of the Oscines. Our preliminary purpose was to assess previous inter-familial taxonomic and phylogenetic hypotheses relating to the Oscines and, when necessary, to elaborate an alternative hypothesis.

\section{MATERIALS AND METHODS}

Tissue samples were obtained from members of 15 oscine families (Table 1). The methods of DNA extraction, amplification and sequencing are described in detail elsewhere (Honda et al. 1999a,b). Fragments of mitochondrial $12 \mathrm{~S}$ and $16 \mathrm{~S}$ rRNA genes were PCR-amplified using the primers L1091, H1478, L2606 and H3056 (Kocher et al. 1989, Hedges et al. 1993).

Alignments for DNA sequences were done based on maximum nucleotide similarity using CLUSTAL X 1.8 (Thompson et al. 1994). The output was later adjusted by eye according to secondary structures of rRNA genes (not given). The resultant topology showed no inconsistency with those derived from the maximum similarity method (gap opening penalty: 5-50, gap extension penalty: 2.5-7.5), although resultant secondary struc-

Table 1. Families of the Oscines used in the present analyses. Taxonomic arrangement follows that of Peters \& successors (1935-1987). The following taxa were incorporated into the analyses: Gallus gallus (accession number: X52392), Coracias caudata (AF173596), and Tyrannus tyrannus (AF173600). (1) denotes the Suboscines. NonPasseriformes orders are (2): Galliformes; (3): Coraciiformes.

\begin{tabular}{ll}
\hline \multicolumn{1}{c}{ Samples } & Family \\
\hline Hirundo rustica & Hirundinidae \\
Motacilla grandis & Motacillidae \\
Pycnonotus sinensis & Pycnonotidae \\
Lanius bucephalus & Laniidae \\
Vanga curvirostris & Vangidae \\
Leiothrix lutea & Timaliidae \\
Phylloscopus coronatus & Sylviidae \\
Cyanoptila cyanomelana & Muscicapidae \\
Parus varius & Paridae \\
Sitta europaea & Sittidae \\
Emberiza spodocephala & Emberizidae \\
Passer montanus & Ploceidae \\
Sturnus cineraceus & Sturnidae \\
Gymnorhina tibicen & Cracticidae \\
Corvus macrorhynchos & Corvidae \\
Tyrannus tyrannus & Tyrannidae ${ }^{1}$ \\
Gallus gallus & Phasianidae ${ }^{2}$ \\
Coracias caudata & Coraciidae ${ }^{3}$ \\
\hline
\end{tabular}


tures were somewhat unstable. We thus used the data based on maximum similarity with default gap penalties excluding insertions and deletions in the following analy. ses.

Also using CLUSTAL X 1.8, neighborjoining (NJ) method (Saitou \& Nei 1987) was performed to infer relationships among the taxa on the basis of Kimura's (1980) two-parameter distance. Maximum-parsimony (MP) analyses were also conducted using the heuristic search option of PAUP* 4.0b (Swofford 1998). In these analyses, no bias was assumed between transition and transversion in an a priori manner, because results from a transition: transversion bias algorithm (1:1-1:10) were consistent in terms of branching topology of nodes 1-6 (see below). Confidences in topology of resultant dendrograms were assessed by 1,000 bootstrap resamplings (Felsenstein 1985).

The interpretation of bootstrap proportions (BPs) is still in a state of uncertainty (see Felsenstein \& Kishino 1993, Hillis \& Bull 1993). We tentatively followed Shaffer et al. (1997), and considered BPs $\geq 90 \%$ as highly significant, $70 \leq \mathrm{BPs}<90 \%$ as marginally significant, and $50 \% \leq \mathrm{BPs}<70 \%$ as constituting only limited evidence of monophyly.

\section{RESULTS}

The 12S rRNA fragment consisted of 412 total sites, 175 of which were variable (Appendix). For the 16S rRNA fragment, there were 469 total aligned sites, 167 of which were variable (Appendix). Interfamilial nucleotide replacements within the Oscines varied from 44 bp (Emberiza spodocephala vs. Passer montanus) to $105 \mathrm{bp}$ (Leiothrix lutea vs. Vanga curvirostris).

The NJ dendrogram was derived from the distance matrix from aligned sequences (Fig. 1A). The monophyly of the Passeriformes was marginally supported (node 1: $\mathrm{BP}=$ $78 \%$ ). The ingroup portion of this dendrogram was divided into two major clusters, of which one, monotypic with Tyrannus, corresponded to the suborder Suboscines. The other major cluster contained all oscine families examined here (node $2: \mathrm{BP}=100 \%$ ). These results did not contradict previous hypotheses, which have argued for the monophylies of the Passeriformes and Oscines based on morphological data (e.g. Bock 1982, Prum 1992, 1993).

The Oscines was divided into two clusters, of which one consisted of Parus, Hirundo, Pycnonotus, Leiothrix and Phylloscopus (node 4: $\mathrm{BP}=83 \%$, henceforth referred to as the "Sylviid Group"). The other cluster (node 3: $\mathrm{BP}=93 \%$ ) was further split into two subclusters, the Lanius - Corvus Gymnorhina - Vanga cluster (node 5: $\mathrm{BP}=$ $92 \%$, henceforth referred to as the "Corvid Group") and the Motacilla - Emberiza Passer - Cyanoptila - Sturnus cluster (node $6: \mathrm{BP}=79 \%$, henceforth referred to as the "Muscicapid Group").

Relationships in the NJ dendrogram (Fig. 1A) showed no inconsistency with MP (Fig. 1B) in terms of branching topology of nodes $1-6$, although nodes 3 and 6 in MP were not supported with BPs $\geq 50 \%$. We therefore recognize the relationships within the Oscines examined here as: "Sylviid Group", ("Corvid Group", "Muscicapid Group")).

\section{DISCUSSION}

Based on morphological data, a number of systematists have attempted to revise the inter-familial sequence and classification of the Oscines (e.g. Mayr \& Amadon 1951, Wetmore 1960). However, their hypotheses severely conflict with each other, and fail to elaborate a sufficiently plausible and reliable basis for the higher-level classification of 


\section{A}
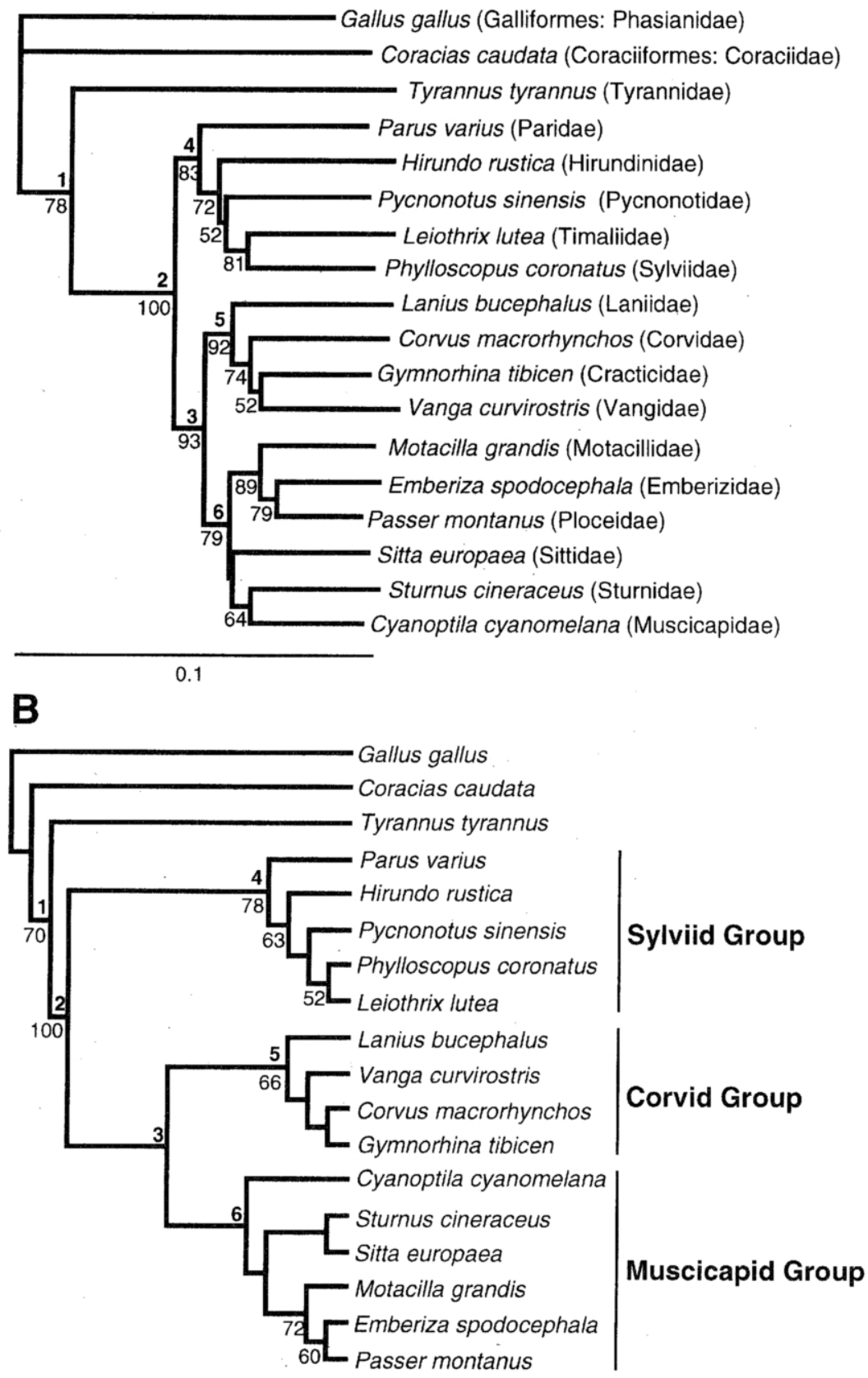

Fig. 1. (A) Neighbor-joining (NJ) dendrogram derived from mitochondrial $12 \mathrm{~S}$ and $16 \mathrm{~S}$ rRNA sequence data. Numbers beneath branches are bootstrap proportions (values $<50 \%$ are omitted). Nodes with bold numbers are identical with MP analyses. Bar equals 0.1 unit of Kimura's (1980) two-parameter distance. (B) Maximum parsimony (MP) cladogram using heuristic option (927 steps, $216 \mathrm{bp}$ informative under the condition of parsimony, consistency index $=0.50$, homoplasy index $=0.50$, retention index $=$ 0.40 ). See above for indications of bootstrapping. 
this suborder.

Phylogenetic relationships inferred from partial sequences of $12 \mathrm{~S}$ and $16 \mathrm{~S}$ rRNA by us indicate the presence of three distinct lineages within the Oscines that are statistically supported in a comprehensive fashion (Felsenstein 1985). This result substantially contradicts previous hypotheses on the inter-familial sequences in which adjacent taxa were presumed to have a close relationship (e.g. Wetmore 1960, Peters \& successors 1935-1987), although it is now obvious that such sequences have no relations with phylogeny. For example, the Paridae and Sittidae, which have been previously assumed to share close affinities in the currently prevailing views, were assigned to different branches corresponding to the "Sylviid Group" and the "Muscicapid Group", by our study.

Our results also contradict the interfamilial taxonomic assemblages, such as the Primitive insectivores (Mayr \& Amadon 1951), Old World insectivores and relatives (Mayr \& Greenway 1956), Group I (Amadon 1957), superfamily Muscicapoidea (Berndt \& Meise 1962) and infraoder Corvi (Cracraft 1981). These classifications seemingly depended on morphological and ecological similarities. We suspect that these previous arrangements of oscine taxa are not only inappropriate, but that they may not reflect their phylogenetic relationships well, as a result of convergence in such phenotypic characters.

In contrast to the previously mentioned morphological studies, Sibley \& Ahlquist (1990) attempted to provide substantial support for avian phylogeny on the basis of DNA-DNA hybridization data. They recognized a primary dichotomy within the Oscines ( $=$ Passeri: Sibley \& Ahlquist 1990), the parvorders Corvida and Passerida, and hypothesized their inter-superfamilial relationships as (Menuroidea, (Meliphagoidea,
Corvoidea)) and (Muscicapoidea, (Sylvioidea, Passeroidea)), respectively (Fig. 2). Our results based on DNA sequence data, however, indicate that the relationships within the Oscines are: ("Sylviid Group", ("Corvid Group", "Muscicapid Group")), contradicting Sibley \& Ahlquist's (1990) phylogenetic hypothesis in suggesting non-monophyly for the Passerida. A number of criticisms have been published on the methods, interpretation of results and applications to systematics used by Sibley \& Ahlquist (1990) (e.g. Gill \& Sheldon 1991, Karajewski 1991, O’Hara 1991, Lanyon 1992, Mindell 1992, Siegel-Causey 1992, Lanyon \& Hall 1994). Our results also point to a risky aspect of their applications of DNA-DNA hybridization data to oscine systematics.

The results of our analyses also indicate that the superfamily Sylvioidea (sensu Sibley \& Ahlquist 1990) is not monophyletic, by assigning Sitta and the other members of this superfamily examined to different phylogenetic lineages (to the "Muscicapid" and "Sylviid" groups, respectively). Furthermore, the family Passeridae (sensu Sibley \& Ahlquist 1990) is also suspected of being non-monophyletic, because the Passerinae (Passer) were shown to be closer to the Fringillidae (Emberiza) than to the Motacillinae of the Passeridae (Motacilla). All these confirm the claim by many authors (see above) regarding the application of DNA-DNA hybridization data to the inferences of inter-subfamilial, as well as higher level, phylogeny in birds.

Our approach, using DNA sequence data, seems to yield useful information on oscine phylogeny, and the three major branches recognized therein are likely to represent three actual lineages within the Oscines. Interestingly, three similar lineages were illustrated in DNA-DNA hybridization analysis by Sheldon \& Gill (1996), although they only recognized the primary dichotomy be- 


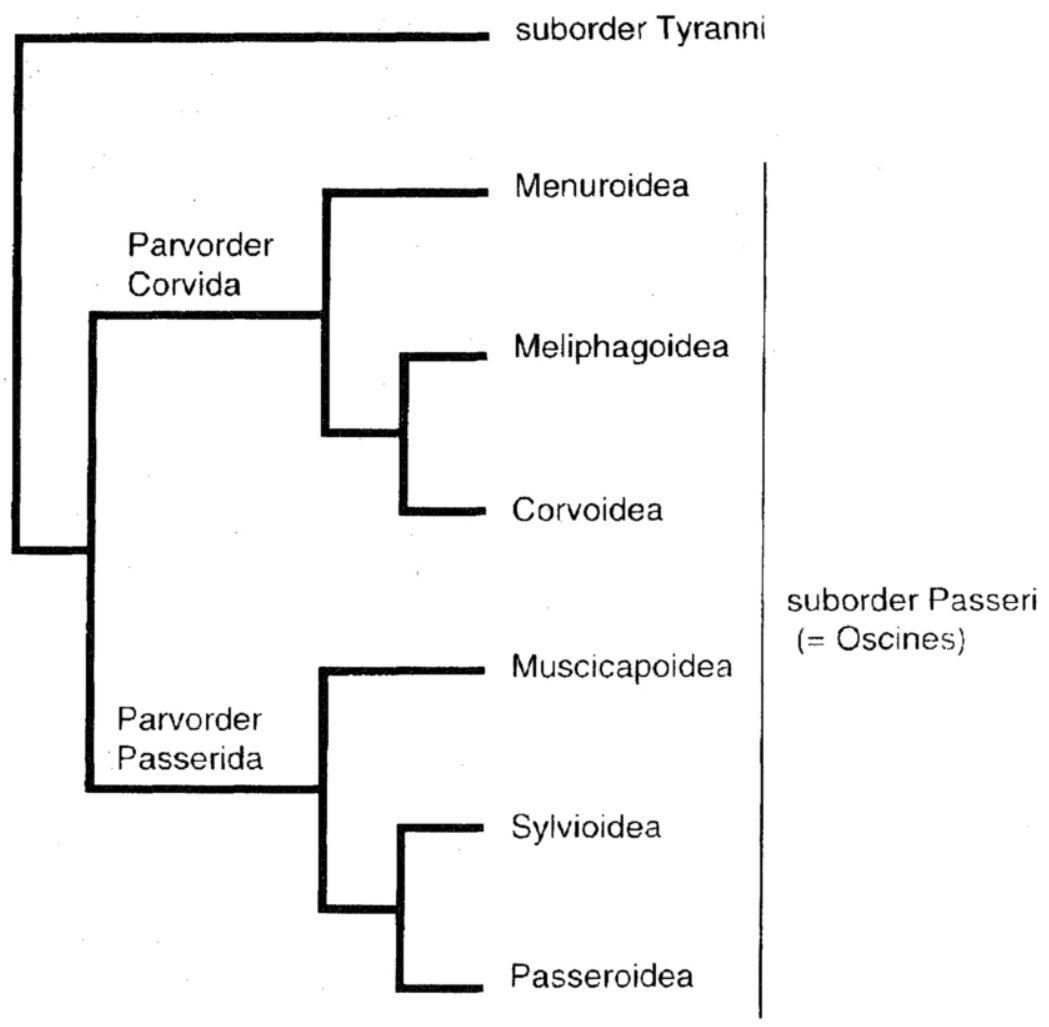

Fig. 2. Phylogenetic relationships of the Passeriformes on the basis of DNA-DNA hybridization data proposed by Sibley \& Ahlquist (1990).

tween the parvorders Corvida and Passerida (sensu Sibley \& Ahlquist 1990) within the Oscines. Moreover, our results revealed the phylogenetic position of the Hirundinidae, which have remained unresolved in previous studies (e.g. Mayr \& Amadon 1951, Cracraft 1981), and of the Timaliidae and Sylviidae which have frequently been regarded as subfamilies of the Muscicapidae (e.g. Mayr \& Amadon 1951, Mayr \& Greenway 1956). In our study, however, the number and the size of samples examined are rather small, and further analyses using samples from more oscine families are strongly desired in order to verify the relationships proposed above.
We would like to thank J: Hughes, R. Kakizawa, N. Ohta and Osaka Museum of Natural History for providing specimens, $\mathrm{M}$. Tsurumi and $\mathrm{S}$. Kobayashi for providing literature, M. Kajita and S. Asai for useful suggestions, and H. Ota for critically reading an earlier draft manuscript. Special thanks are due to N. Satoh and members of his laboratory for continuous support for our laboratory experiments. Experiments were also carried out using the facilities of Kyoto University Museum through the courtesy of $\mathrm{T}$. Nakabo and M. Motokawa. Our research was partially supported by Grants-in-Aid from the Japan Ministry of Education, Science, Sports and Culture (Overseas Researches No. 01041079 to S. Yamagishi), and the Nakayama Foundation for Human Science (to M. Honda). 


\section{LITERATURE CITED}

Amadon D., 1957. Remarks on the classification of the perching birds (order Passeriformes). Proc. Zool. Soc. Calcutta Mookerjee Mem. Vol.: 259-268.

Ames, P. L., 1971. The morphology of the syrinx in passerine birds. Bull. Peabody Mus. Nat. Hist. 37: 1-94.

Barrowglough, G., 1992. Biochemical studies of the higher-level systematics of birds. Bull. Brit. Ornithol. Club. 112A: 39-52.

Berndt, G. \& Meise, W., 1962. Naturgeschichte der Vögel Vol. 2. Franckh'sche Verlags, Stuttgart.

Bleiweiss, R., Kirsch, J. A. \& Matheus, J. C., 1994. DNA-DNA hybridization evidence for subfamily structure among hummingbirds. Auk 111: 8-19.

Bleiweiss, R. Kirsch, J. A. \& Kuhl, W., 1995. Interference of heparin with the polymerase chain reaction. Auk 112: 87-97.

Bock, W. J., 1982. Aves. Parker, P. S. (ed.) Synopsis and Classification of Living Organisms. Vol. 2: 976-1015. McGraw-Hill, New York.

Bock, W. J. \& Farrand, J. Jr., 1980. The numbers of species and genera of recent birds: a contribution to comparative systematics. Am. Mus. Novit. 2703: 1-29.

Chikuni, K., Minaka, N. \& Ikenaga, H., 1996. Molecular phylogeny of some Passeriformes, based on cytochrome b sequences. J. Yamashina Inst. Ornithol. 28: 1-8.

Cracraft, J., 1981. Toward a phylogenetic classification of the recent birds of the world (class Aves). Auk 98: 681-714.

Felsenstein, J., 1985. Confidence limits on phylogenies: an approach using the bootstrap. Evolution 39: 783-791.

Felsenstein, J. \& Kishino, H., 1993. Is there something wrong with the bootstrap on phylogeny? A reply to Hillis and Bull. Syst. Biol. 42: 193-200.

Gill, F. B. \& Sheldon, F. H., 1991. Review of Sibley and Ahlquist, Phylogeny and Classification of Birds. Science 252: 1003-1005.

Harshman, J., 1994. Reviewing the tapestry: what can we learn from Sibley and Ahlquist (1990)? Auk 111: 377-388.
Hedges, S. B., Nussbaum, R. A. \& Maxson, L. R., 1993. Caecilian phylogeny and biogeography inferred from mitochondrial DNA sequences of the 12S rRNA and 16S rRNA genes (Amphibia: Gymnophiona). Herpetol. Monogr. 7: 64-76.

Hillis, D. M. \& Bull, J. J., 1993. An empirical test of bootstrapping as a method for assessing confidence in phylogenetic analysis. Syst. Biol. 42: 182-192.

Honda, M., Ota, H., Kobayashi, M., Nabhitabhata, J., Yong, H.-S. \& Hikida, T., 1999a. Phylogenetic relationships of the flying lizards, genus Draco (Reptilia, Agamidae). Zool. Sci. 16: 535-549.

Honda, M., Ota, H., Kobayashi, M., Nabhitabhata, J., Yong, H.-S. \& Hikida, T., 1999b. Evolution of Asian and African lygosomine skinks of the Mabuya group (Reptilia: Scincidae): a molecular perspective. Zool. Sci. 16: 979-984.

Karajewski, C., 1991. Review of Sibley and Ahlquist, Phylogeny and Classification of Birds. Auk 108: 987-990.

Kimura, M., 1980. A simple method for estimating evolutionary rates of base substitutions through comparative studies of nucleotide sequences. J. Mol. Evol. 16: 116-120.

Klicka, J., Johnson, K. P. \& Lanyon, S. M., 2000. New world nine-primaried oscine relationships: constructing a mitochondrial DNA framework. Auk 117: 355-365.

Kocher, T. D., Thomas, W. K., Meyer, A., Edwards, S. V., Pääbo, S., Villablanca, F. X. \& Wilson, A. C., 1989. Dynamics of mitochondrial DNA evolution in animals: amplifications and sequencing with conserved primers. Proc. Nat. Acad. Sci. USA 86: 189-191.

Lanyon, S. M., 1992. Review of Sibley and Ahlquist, Phylogeny and Classification of Birds. Condor 94: 304-307.

Lanyon, S. M. \& Hall, J. G., 1994. Re-examination of barbet monophyly using mitochondrialDNA sequence data. Auk 111: 389-397.

Lovette, I. J. \& Bermingham, E., 2000. c-mos variation in songbirds: molecular evolution, phylogenetic implications, anc comparisons with mitochondrial differentiation. Mol. Biol. Evol. 17: 1569-1577.

Mayr, E. \& Amadon, D., 1951. A classification of recent birds. Am. Mus. Novit. 1496: 1-42.

Mayr, E. \& Greenway, C. Jr., 1956. Sequence of 
passerine family (Aves). Breviora 58: 1-11.

Mindell, D. P., 1992. DNA-DNA hybridization and avian phylogeny. Syst. Biol. 41: 126-134.

Mindell, D. P., Sorenson, M. D., Huddkeston, C. J., Miranda, H. C. Jr., Knight, A, Sawchuk, S. J. \& Yuri, T., 1997. Phylogenetic relationships among and within select avian orders based on mitochondrial DNA. Mindell, D. P. (ed.) Avian Molecular Evolution and Systematics: 214-247. Academic Press, San Diego.

Miskimen, M., 1963. The syrinx in certain tyrant flycatchers. Auk 80: 156-165.

Mooers, A. O. \& Cotgreave, P., 1994. Sibley and Ahlquist's tapestry dusted off. Trends Ecol. Evol. 9: 458-459.

O'Hara, R., 1991. Review of Sibley and Ahlquist, Phylogeny and Classification of Birds. Auk 108: $990-994$.

Peters J. L. \& successors., 1935-1987. Check-list of Birds of the World I-XVI. Mus. Comp. Zool., Cambridge.

Prum, R. O., 1992. Syringeal morphology, phylogeny, and evolution of the Neotropical manakins (Aves: Pipridae). Am. Mus. Novit. 3043: 1-65.

Prum, R. O., 1993. Phylogeny, biogeography, and evolution of the broadbills (Eurylaimidae) and asities (Philepittidae) based on morphology. Auk 110: 304-324.

Raikow, R. J., 1987. Hindlimb myology and evolution of the Old World suboscines passerine birds (Acanthisittidae, Pittidae, Philepittidae, Eurylaimidae). AOU Ornithol. Monogr. 41: 181.

Saitou, N. \& Nei, M., 1987. The neighbor-joining method: a new method for reconstructing phylogenetic trees. Mol. Biol. Evol. 4: 406-425.

Shaffer, H. B., Meylan, P. \& McKnight, M. L., 1997. Tests of turtle phylogeny: molecular, morpho- logical, and paleontological approaches. Syst. Biol. 46: 235-268.

Sheldon, S. H. \& Gill, F. B., 1996. A reconsideration of songbirds phylogeny, with emphasis on the evolution of titmice and their sylvioid relatives. Syst Biol. 45: 473-495.

Sibley, C. G., 1970. A comparative study of eggwhite proteins of passerine birds. Bull. Peabody Mus. Nat. Hist. 32: 1-131.

Sibley, C. G. \& Ahlquist, J. E., 1972. A comparative study of egg-white proteins of nonpasserine birds. Bull. Peabody Mus. Nat. Hist. 39: $1-276$.

Sibley, C. G. \& Ahlquist, J. E., 1990. Phylogeny and Classification of Birds: A Study in Molecular Evolution. Yale Univ. Press, New Haven.

Siegel-Causey, D., 1992. Review of Sibley and Monroe, Distribution and Taxonomy of Birds. Auk 109: 939-944.

Swofford, D. L., 1998. A Phylogenetic Analysis Using Parsimony (*and Other Methods) ver 4.0. Massachusetts.

Thompson, J. D., Higgins, G. \& Gibson, T. J., 1994. CLUSTAL W: improving the sensitivity of progressive multiple sequence alignment through sequence weighting, position specific gap penalties and weight matrix choice. Nucl. Acids Res. 22: 4673-4680.

Tuinen, M. van, Sibley, C. G. \& Hedges, S. B., 2000. The early history of modern birds inferred from DNA sequences of nuclear and mitochondrial ribosomal genes. Mol. Biol. Evol. 17: 451-457.

Wetmore, A., 1960. A classification of the birds of the world. Smiths. Misc. Coll. 117: 1-22.

(Received 12 August 2000; Accepted 11 December 2000)

Appendix. Aligned sequences of a $881 \mathrm{bp}$ segment of the 12S and 16S rRNA genes. The initial $412 \mathrm{bp}$ in each row correspond to the 12S rRNA gene domain. The 16S rRNA gene domain begins at the asterisk. A dot indicates an identity with the sequence of Gallus gallus; A dash denotes a gap site. 

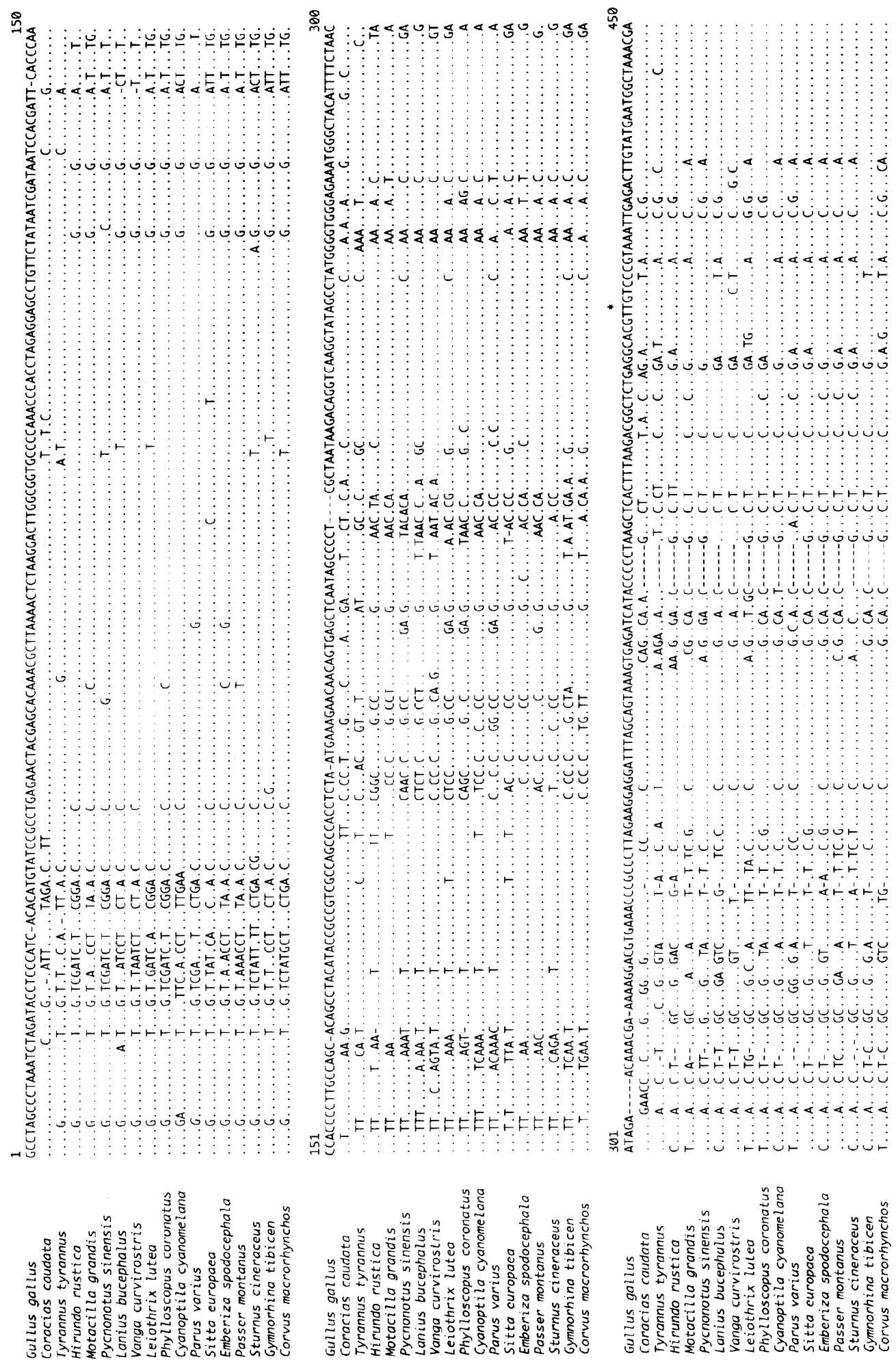


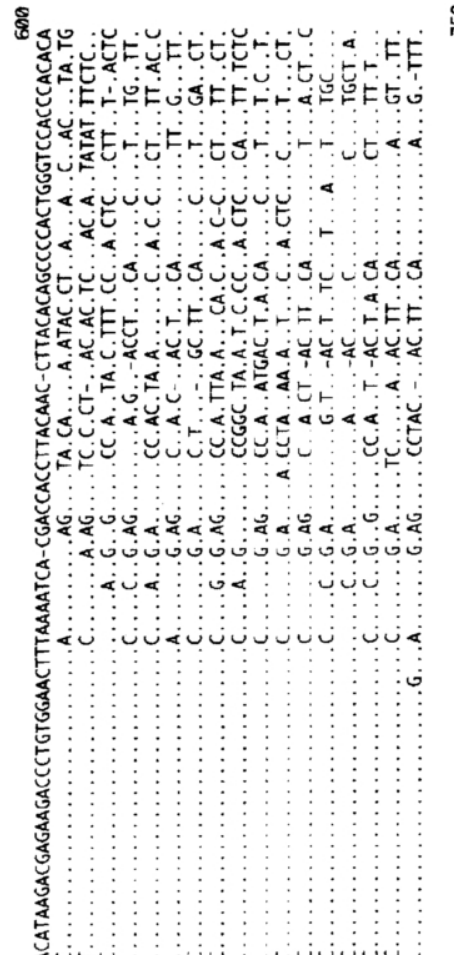

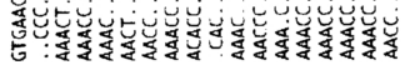

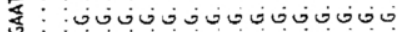
أن

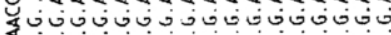
过:

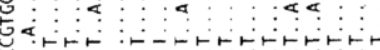

政

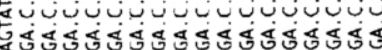
这

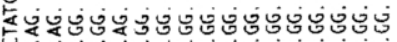

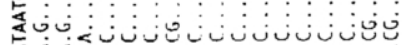

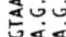

نَّة

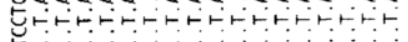
比
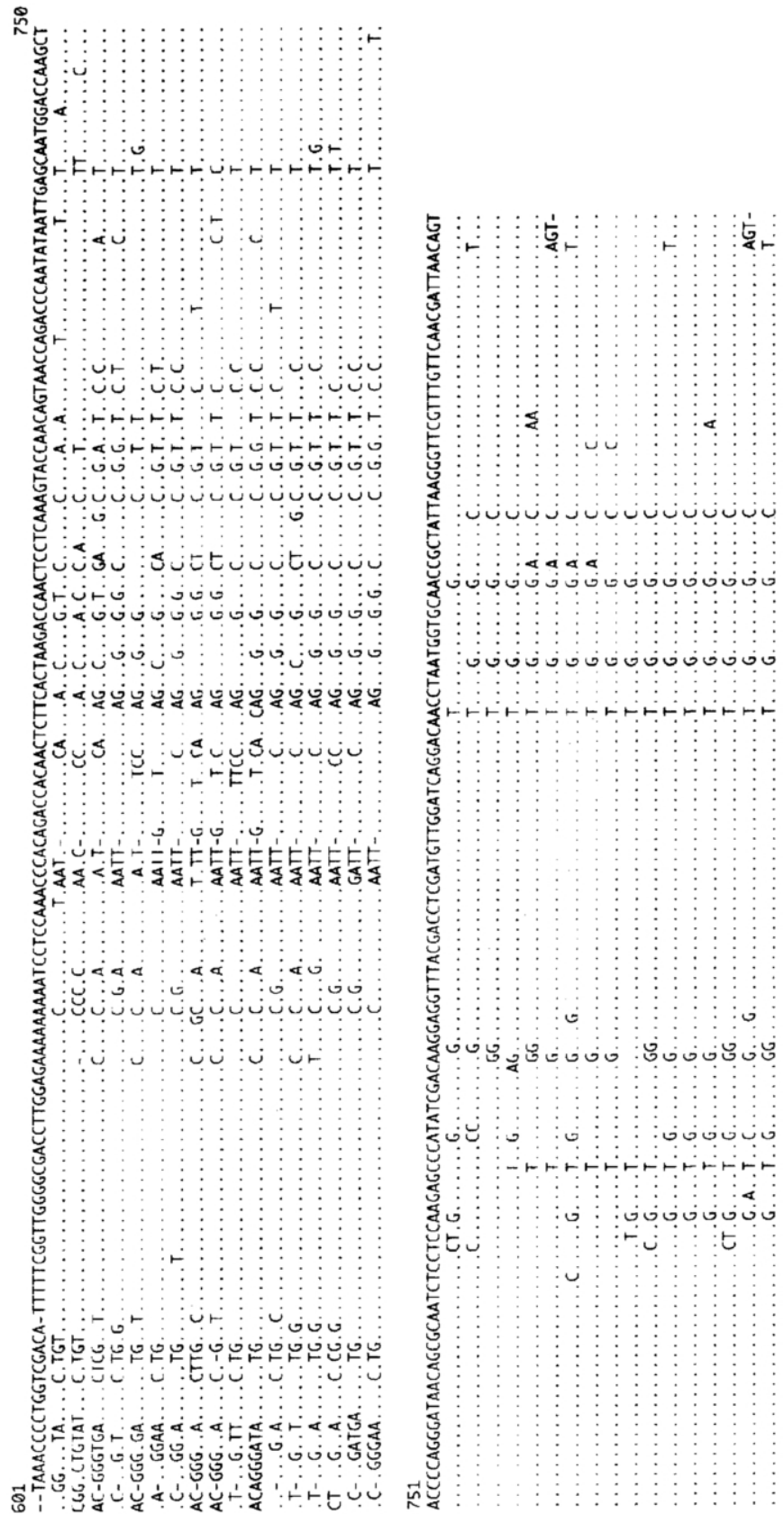

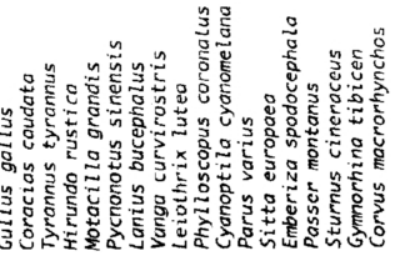

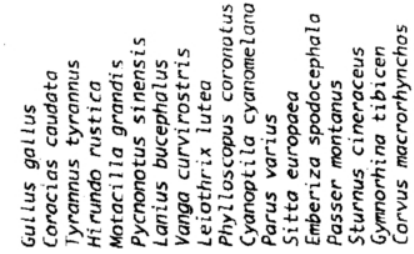




\title{
鳴禽亜目の系統に関する分子生物学的考察,
} 特に科間の関係について

(Molecular Perspective for the Oscine Phylogeny, with Special

Reference to the Inter-familial Relationships. 49: 175-184)

\author{
本多正尚・山岸 哲 \\ 京都大学大学院理学研究科生物科学専攻 \\ ₹606-8502 京都市左京区北白川追分町
}

\begin{abstract}
鳴禽亜目の系統関係を予備的に検討するために鳴禽ウカラ科からなるウグイスグループ，モズ科・オオ八 亜目15科から得られたミトコンドリア DNA 12 S およ シモズ科・フエガラス科・カラス科からなるカラスグ び16S リボゾーム RNA 遺伝子の塩基配列を分析した．ループ）が存在することを示唆した．これは Sibley \& 2 つの塩基配列を統合したデー夕（881塩基対）から得 Ahlquist（1990）の DNA-DNA ハイブリダイゼイショ られた結果は鳴禽亜目に少なくとあ 3 つの系列（セキ ン法に基づく系統仮説を全く支持しなかった，さらに， レイ科・ヒタキ科・ゴジュウカラ科・ホオジロ科・八 シジュウカラ科とゴシュウカラ科が近縁でないこと等, タオドリ科・ムクドリ科からなるヒタキグループ，七これまでの形態学的データに基づく鳴离亜目の科以上 バリ科・ヒヨドリ科・チメドリ科・ウグイス科・シジュの分類体系に関する問題点が示唆された.
\end{abstract}

